\title{
Potentiation of aminoglycoside antibiotic activity using the body fat from the snake Boa constrictor
}

\author{
Felipe S. Ferreira, ${ }^{* 1}$ Nalba L. G. Silva, ${ }^{2}$ Edinardo F. F. Matias, ${ }^{3}$ \\ Samuel V. Brito, ${ }^{1}$ Francisco G. Oliveira, ${ }^{3}$ José G. M. Costa, ${ }^{3}$ \\ Henrique D. M. Coutinho, ${ }^{3}$ Waltécio O. Almeida, ${ }^{3}$ Rômulo R. N. \\ Alves $^{3}$
}

${ }^{1}$ Departamento de Sistemática e Ecologia, Programa de Pós-graduação em Ciências Biológicas (Zoologia), Universidade Federal da Paraíba, Brazil, ${ }^{2}$ Departamento de Biologia, Universidade Estadual da Paraiba, Brazil, ${ }^{3}$ Departamento de Química Biológica, Universidade Regional do Cariri, Brazil.

\begin{abstract}
Boa constrictor is widely used in traditional communities in many different folk remedies and products derived from it are sold in public markets throughout northeastern Brazil and as its body fat has many different therapeutic indications as a folk remedy. The present work evaluates the antibacterial activity of the body fat from the snake Boa constrictor when employed either alone or in combination with antibiotics and discusses the ecological implications of the use of this traditional remedy. Oil (OBC) was extracted from body fat located in the ventral region of $B$. constrictor using hexane as a solvent. The antibacterial activity of OBC was tested against standard as well as multi-resistant lines, either alone and in combination with antibiotics. OBC did not demonstrate any relevant antibacterial activity against standard or multidrug-resistant bacterial strains. OBC showed synergistic activity when combined with the aminoglycoside antibiotics. Our results indicate that the body fat of Boa constrictor does not possess bactericidal activity, from the clinical point of view, but when combined with an antibiotic, the fat demonstrated a significant synergistic activity.
\end{abstract}

Revista Brasileira de Farmacognosia Brazilian Journal of Pharmacognosy 21(3): 503-509, May./Jun. 2011
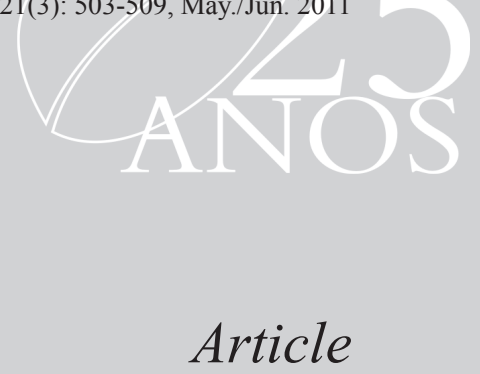

Received 25 Aug 2010

Accepted 16 Nov 2010 Available online 20 May 2011

ISSN 0102-695X doi: $10.1590 / \mathrm{S} 0102-695 \mathrm{X} 2011005000088$

\section{Introduction}

Biodiversity has been a source of products for the treatment of diseases, and thus, people have developed various practices and techniques to exploit biodiversity, accumulating a broad knowledge of the therapeutic and medicinal properties of animals, plants and minerals, which represent important alternatives in the substitution of allopathic medications (Kursar et al., 2007; Alves, 2009).

Animals and products derived from them, are essential ingredients in the preparation of many traditional remedies and have probably been used since prehistoric times (Lev, 2003; Silva et al., 2004; Almeida, 2007; Ferreira et al., 2009a,b). Alves (2008) documented the use of at least 290 different animal species used in folk medicine in Brazil, with Boa constrictor (Linnaeus, 1758) being frequently sought after in many different regions of that country (CostaNeto, 1999; Alves et al., 2007a,b; 2009).

B. constrictor, Boidae, is a snake that can reach a mean length of $3.5 \mathrm{~m}$; it has an arboreal habit but can display terrestrial habits; and it shows nocturnal and diurnal activity (Vanzolini et al., 1980). This snake feeds on mammals, birds and lizards (Henderson et al., 1995). It is found in neotropical areas (Mexico, Central America and South America, Antilles, and Dominica and St. Lucia islands). B. constrictor snakes are viviparous, and generally, copulation occurs in the fall up to the beginning of winter. Litter size can vary from 18 to 41 offspring (Peters et al., 1986).

$B$. constrictor is widely used in traditional communities in many different folk remedies (CostaNeto, 2000; Andrade \& Costa-Neto, 2006; Alves et al., 2007b; Alves et al., 2008; Alves, 2008; Alves et al. 2009a), and products derived from it are sold in public markets throughout northeastern Brazil (Alves \& Rosa 2007a).

The most widely used zootherapeutic product derived from B. constrictor is its fat (Alves, 2009). Among the various applications attributed to this oil are treatments for the following ailments: rheumatism, lung 
disease, thrombosis, boils, tuberculosis, stomach ache, edema, snake bite, cancer, ache, swelling, to prevent abortion, pain in the body, inflammation, athlete's foot, calluses, tumors, cracks in the sole of the feet, goiter, earache, sore throat, arthrosis, insect sting, dog bite, erysipelas, thrombosis, asthma, neck strain, strain muscle (Alves, 2009; Alves \& Rosa, 2006, 2007a,b).

Many of the illnesses treated with products obtained from $B$. constrictor are associated with bacterial infections, which suggests that they may contain antibacterial components, but no laboratory studies evaluating the efficiency of this popular remedy have yet been undertaken.

There has been increasing attention paid to animals, both vertebrates and invertebrates, as sources of new medicines (Chivian, 2002). Animals have been methodically tested by pharmaceutical companies as sources of drugs for modern medical science (Cox, 1990), and the current percentage of animal sources for producing essential medicines is quite significant (Alves \& Rosa, 2007a). Hunt \& Vicent (2006) and Mayer \& Gustafson (2008) stated that faunistic resources have been tested for the production and/or isolation of bioactive compounds. Rashid et al. (2009) isolated and purified polysaccharides from the sponge Celtodoryx girardae that possess an important antiviral activity against Herpes simplex. Stankevicins et al. (2008) evaluated the anti-mutagenic activity of extracts of the sponge Arenosclera brasiliensis. Barros et al. (2007) isolated a type of heparin from the ascidia of Styela plicata with a potent anesthetic activity.

On the other hand, studies have pointed to the inefficacy of some products utilized in traditional medicine in the treatment of some diseases and/or symptoms. Ferreira et al. (2009c) showed that the body fat of Tupinambis merianae does not inhibit bacterial growth, and thus it is not recommended for the treatment of diseases involving earache or infection. Of nearly 25,000 applications for registering traditional medicines that were examined by Malaysian authorities, for example, $37.3 \%$ were rejected based on considerations of either their safety or efficiency (Ang $\&$ Lee, 2006). These results indicate the necessity of evaluating the biological activity of natural products utilized in traditional medicine.

Studies on traditional uses of animalderived resources must be coupled to considerations of conservation biology and public health policies; however, for the sustainable management of natural resources that have been highlighted by bioprospecting, such studies are of primal importance for their sustainable use (Alves, 2009; Ferreira et al., 2009b).

The present work evaluates the antibacterial activity of the body fat of Boa constrictor when employed either alone or in combination with antibiotics and discusses the ecological implications of the use of this traditional remedy.

\section{Materials and Methods}

\section{Zoological material}

Specimen of Boa constrictor were collected in the municipality of Crato ( $7^{\circ} 14^{\prime} 03^{\prime \prime} \mathrm{S}$ x $39^{\circ} 24^{\prime} 34^{\prime \prime}$ W), Ceará State, Brazil during the month of November 2009. The animals were anesthetized with ketamine (50 $\mathrm{mg} / \mathrm{mL}$ ), sacrificed to remove their body fat, and their remains deposited in the Laboratório de Zoologia da Universidade Regional do Cariri (LZ-URCA 0676).

\section{Preparation of the oil from Boa constrictor $(O B C)$}

Oil was extracted from the body fat located in the ventral region of the snake. Extraction was undertaken for four hours in a Soxhlet apparatus using hexane as the solvent. After the mixture was decanted and filtered, the oil was dried in a water-bath at $70{ }^{\circ} \mathrm{C}$ for $2 \mathrm{~h}$ and subsequently stored in a freezer pending further analyses. A test solution of purified fat was prepared from $10 \mathrm{mg}$ of the frozen sample dissolved in $1 \mathrm{~mL}$ of dimethylsulfoxide (Merck, Darmstadt, Germany), yielding an initial concentration of $10 \mathrm{mg} /$ $\mathrm{mL}$; this solution was then further diluted to $1024 \mu \mathrm{g}$ / $\mathrm{mL}$.

\section{Strains}

Experiments were performed with clinical isolates of Escherichia coli (EC27), resistant to low levels of neomycin and gentamicin, as well as to tobramycin, amikacin and kanamycin; and with isolates of Staphylococcus aureus 358 (SA358) resistant to several aminoglycosides (Freitas et al., 1999; Coutinho et al., 2005). The EC-ATCC25922 strain of Escherichia coli, the SA- ATCC12692 strain of Staphylococcus aureus, the PV-ATCC 13315 strain of Proteus vulgaris and the PA- ATCC 15442 strain of Pseudomonas aeruginosa were used as positive controls and were maintained on heart infusion agar slants (HIA, Difco). Prior to the assays, the cells were grown overnight at $37^{\circ} \mathrm{C}$ in brain heart infusion (BHI, Difco).

\section{Drugs}

Gentamicin, kanamycin, amikacin, neomycin were obtained from Sigma Chemical Corp., St. Louis, MO, USA. All of the drugs were dissolved in sterile water before use. 


\section{Drug susceptibility test}

The minimum inhibitory concentrations (MIC) of the putative $\mathrm{OBC}$ antibiotics were determined in $\mathrm{BHI}$ by microdilution assays using suspensions of $10^{5} \mathrm{cfu} / \mathrm{mL}$ and drug concentrations ranging from 1 to $1024 \mu \mathrm{g} / \mathrm{mL}$ (in two-fold serial dilutions) (Javadpour et al., 1996). MIC was defined as the lowest drug concentration at which no bacterial growth was observed. For the evaluation of extracts and fractions as modulator of antibiotic activity, the MIC of the antibiotics were determined in the presence of each extract and fraction $(32 \mu \mathrm{g} / \mathrm{mL})$ at sub-inhibitory concentrations, and the plates were incubated for $24 \mathrm{~h}$ at $37^{\circ} \mathrm{C}$.

EC27 and SA358 strain were tested by the microdilution checkerboard techinique (Eliopoulos \& Moellering, 1991). In order to evaluate the activity of combinations of drugs (amikacin and neomycin), fractional inhibitory concentration (FIC) indices were calculated as $\mathrm{FIC}^{\mathrm{A}}+\mathrm{FIC}^{\mathrm{B}}$, where $\mathrm{FIC}^{\mathrm{A}}$ and $\mathrm{FIC}^{\mathrm{B}}$ represent the minimum concentrations that inhibited the bacterial growth for drugs $\mathrm{A}$ and $\mathrm{B}$, respectively: $\mathrm{FIC}^{\mathrm{A}}=\mathrm{MIC}^{\mathrm{A}}$ combination/ $\mathrm{MIC}^{\mathrm{A}}$ alone and $\mathrm{FICB}=$ MICBcombination/ MICBalone. FIC index was interpreted as follows: synergistic $(<0.5)$, additive $(0.5-1)$, indifferent $(>1)$ or antagonistic $(>4)$.

\section{Results}

OBC did not demonstrate any relevant antibacterial activity against standard or multidrugresistant bacterial strains (Table 1), demonstrating that there is no pharmacological basis for the use of these zootherapeutic products as an antibiotic for the treatment of diseases such as earache or sore throat generally caused by bacteria.

Table 1. Minimum inhibitory concentrations (MIC) of body fat from snake Boa constrictor (OBC) against standard or multidrug-resistant bacterial strains $(\mu \mathrm{g} / \mathrm{mL})$.

\begin{tabular}{|c|c|c|c|c|c|c|}
\hline & EC27 & $\begin{array}{c}\text { EC ATCC } \\
25922\end{array}$ & $\begin{array}{l}\text { SA } \\
358\end{array}$ & $\begin{array}{c}\text { SA ATCC } \\
12692\end{array}$ & $\begin{array}{c}\text { PV ATCC } \\
13315\end{array}$ & $\begin{array}{c}\text { PA ATCC } \\
15442\end{array}$ \\
\hline $\mathrm{OBC}$ & 512 & 512 & 512 & 512 & 256 & 512 \\
\hline
\end{tabular}

OBC was tested for bactericidal activity, against multidrug-resistant strains, when combined with an antibiotic (Table 2). OBC showed synergistic activity when combined with the aminoglycoside antibiotics with exception of kanamycin for EC27, and gentamicin for SA358. The results indicate the effectiveness of the use of body fat of $B$. constrictor in combination with antibiotics for the treatment of diseases caused by bacteria. With respect to tests of antibiotic-modifying activity, the results obtained show the OBC has marked modulatory activity when combined with aminoglycoside antibiotics. In the assays carried out with EC27, OBC synergism was observed with all antibiotics except kanamycin. The MIC of amikacin, neomycin and gentamicin against EC27 were 156, 625 and $19.5 \mu \mathrm{g} / \mathrm{mL}$, respectively. However, when these antibiotics were combined with $32 \mu \mathrm{g} / \mathrm{mL}$ OBC, the MIC decreased to $4.9,4.9$ and $2.4 \mu \mathrm{g} / \mathrm{mL}$, respectively (Table 2). In the assays carried out with SA358, there was no synergism with the combination of gentamicin and OBC. The MIC of kanamycin, amikacin and neomycin against SA358 were $312.5 \mu \mathrm{g} / \mathrm{mL}$, but when the antibiotics were combined with $\mathrm{OBC}$, the MIC decreased to 4.9, 2.4 and $2.4 \mu \mathrm{g} / \mathrm{mL}$, respectively (Table 2). These are the first data on the drug-modulating activity $B$. constrictor fat against bacterial strains.

Table 2. Minimum inhibitory concentrations (MIC) of body fat from snake Boa constrictor (OBC) against multidrugresistant bacterial strains alone and combined with aminoglycosides $(\mu \mathrm{g} / \mathrm{mL})$.

\begin{tabular}{ccccc}
\hline Antibiotic & $\begin{array}{c}\text { MIC } \\
\text { EC27 }\end{array}$ & $\begin{array}{c}\text { OBC }(32 \mu \mathrm{g} / \mathrm{mL}) \\
+ \text { antibiotic }\end{array}$ & $\begin{array}{c}\text { MIC } \\
\text { SA358 }\end{array}$ & $\begin{array}{c}\text { OBC }(32 \mu \mathrm{g} / \mathrm{mL}) \\
+ \text { antibiotic }\end{array}$ \\
\hline OBC & 512 & - & 512 & - \\
Kanamycin & 1250 & 1250 & 312.5 & 4.9 \\
Amikacin & 156 & 4.9 & 312.5 & 2.4 \\
Neomycin & 625 & 4.9 & 312.5 & 2.4 \\
Gentamicin & 19.5 & 2.4 & 4.9 & 4.9 \\
\hline
\end{tabular}

The checkboard test showed additive and synergistic effect of the OBC when combined with amikacin and neomycin against EC27 and SA358 (Table $3)$. About the checkboard test, a combination of $\mathrm{OBC}$ and amikacin against EC27 showed a $\mathrm{FIC}_{\mathrm{I}}=0.5$, while a combination of $\mathrm{OBC}$ and neomycin showed a $\mathrm{FIC}_{\mathrm{I}}=$ 1. Both aminoglycoside antibiotics tested presented an additive effect. A combination of $\mathrm{OBC} /$ amikacin and OBC/neomycin against SA358 showed a $\mathrm{FIC}_{\mathrm{I}}=0.25$ demonstrating a synergistic effect.

Table 3. Minimum inhibitory concentrations (MIC) of body fat from snake Boa constrictor (OBC) and the effect of combinations with amikacin and neomycin.

\begin{tabular}{lcc}
\hline & EC 27 & FIC index (type of interaction) \\
\hline OBC/Amikacin & $\geq 1024 / 16$ & 0.5 (additive) \\
OBC/Neomycin & $\geq 1024 / 64$ & 1 (additive) \\
& SA 358 & \\
OBC/Amikacin & $\geq 1024 / 32$ & 0.25 (synergistic) \\
OBC/Neomycin & $\geq 1024 / 32$ & 0.25 (synergistic) \\
\hline
\end{tabular}

\section{Discussion}

The search for new pharmaceuticals derived from natural products has intensified in recent years (Kong et 
al., 2009). Harvey (2008) reported that 225 drugs from natural sources were in developmental stages and, of these, 24 had been extracted from animals. The search for medicines and genes from nature has been promoted as a non-destructive use of habitat that promotes human health as well as supporting economic development and conservation (Kursar et al., 2007).

The present study showed the inefficacy of OBC, from the clinical point of view, against diseases caused by bacteria when applied alone. The lowest inhibitory concentration of $\mathrm{OBC}$ was $256 \mu \mathrm{g} / \mathrm{mL}$ against the strain $P$. vulgaris. For the other bacterial strains, the MIC of OBC was $512 \mu \mathrm{g} / \mathrm{mL}$. These concentrations are considered ineffective, because a very high dose would be necessary to reach such concentration in plasma (Houghton et al., 2007). Falodum et al. (2008) evaluated the bactericidal activity of $B$. constrictor fat the bacterial strains $S$. aureus, $B$. subtilis, Streptococcus spp, E. coli and P. aeruginosa utilizing diffusion disks. In this work, the authors stated that the body fat of $B$. constrictor possesses antibacterial activity. However, the method utilized does not make it possible to determine a concentration at which the fat inhibits bacterial growth, as can be determined using a serial dilution method (Hadacek \& Greger, 2000). Therefore, antibacterial activity can be indicated but not compared with the data obtained in this work.

Fatty acids can show antibacterial activity, mainly the unsaturated ones, by affecting the endogenous synthesis of bacterial fatty acids (Zheng et al., 2005). Body fat of B. constrictor contains 62 and $38 \%$ of unsaturated and saturated fatty acids, respectively. The composition of OBC was as follows: myristic acid, palmitic acid, stearic acid, palmitoleic acid, oleic acid, vaccenic acid, linoleic acid, arachidonic acid (McCue, 2008).

Os results obtained for Boa constrictor differ from those obtained for other reptiles. For example, Ferreira et al. (2009c) evaluated the modulatory activity of the fat of Tupinambis merianae against bacterial strains. The results indicate that $T$. merianae fat did not increase the effectiveness of aminoglycosides against the bacterial strains tested. The MIC of amikacin and neomycin combined with body fat of $T$. merianae demonstrated no potentiation of those antibiotics against either E. coli or S. aureus. Both of the aminoglycosides tested (kanamycin and gentamicin) demonstrated a reduction in their effectiveness against $E$. coli or $S$. aureus when combined with body fat of $T$. merianae. A possible explanation would be the percentage of unsaturation observed between these fats, where the greater percentage of unsaturated fats was found in OTM.

Various products from animals have been tested against bacteria showing effective biological activity. Bosch et al. (2009) identified and isolated the peptide called hydramacine-1 from Hydra with antibacterial activity. Li et al. (2009) isolated a new sesquiterpene quinone from the sponge Dysidea villosa, with potential anti- bacterial activity. Adhya et al. (2009) isolated the lectin, molecular mass of $47 \mathrm{kDa}$, from the bivalve Macoma birmanica, which inhibited the growth of Grampositive and Gram-negative bacteria. Stow \& Beattie (2008) reviewed the defense mechanisms of social insects against microorganisms and stated that some of these compounds such as terpenoids and peptides can be utilized in medicine in the fight against pathogenic bacteria. Two proteins obtained from Branchiostoma belcheri demonstrated bactericidal activity (Fan et al., 2008; Ju et al. 2009). Wang et al. (2009) isolated a protein (hepcidine) of immune system of the fish Pseudosciaena crocea demonstrating antibacterial and antifungal activity. Conlon et al., (2006) reported on peptides of the japonicine-2 type with antibacterial activity from extracts of the skin of the frog Rana chaochiaoensis. Park et al. (2009) isolated a protein of the lactoforicine type from Bos taurus milk with activity against bacteria.

Few works have shown antibiotic-modifying activity for zootherapeutic products. Coutinho et al. (2009; 2010) reported on the activities of decoctions of Nasutitermes corniger ("cupim") against multidrug resistant bacteria. In that study, the decoctions showed synergistic activity when combined with neomycin.

Chin et al. (2006) stated that $87 \%$ of the categories of diseases that affect humans can be treated with natural products. Alves et al. (2007a, b) and Alves et al. (2009a) have warned about the potential for over exploitation of natural resources used by traditional medical practitioners. Hunt \& Vincent (2006) warned that bioprospecting natural resources for the production of new pharmaceuticals could result in the over-exploitation of biodiversity, with direct and negative impacts on those sources. Various species of animals utilized in traditional medicine are threatened by extinction and are openly commercialized. There is no information on the biological activity of these resources, but their trafficking is common (Alves \& Rosa, 2005, 2007c).

Servheen (1999) believes that fourteen species of bears, on the IUCN list, are commercialized in and outside of China for medicinal use. In Brazil, Alves et al. (2009b) listed a total of 44 reptile species used for medicinal or magic/religious purposes, and 23 (52.3\%) are considered to be threatened with extinction. Pharmacological tests of products derived from animals threatened by extinction is of extreme importance, because validating or not this practice and proposing measures for rational and sustainable use are indispensable for the maintenance of the species (Albuquerque et al., 2009; Alves et al., 2009b). The case of the rhinoceros is an example. The use of rhinoceros horn in traditional medicine has been pointed out as the principal cause of the decline in the population of these animals 
(Lee, 1999). Although zootherapeutic products from this species have some proven value, as demonstrated by the work of But et al. (1990), who found substantial antipyretic activity in rhinoceros horn, the impact of such uses on the natural populations of these animals should be better analyzed, and alternative therapeutics should be considered. Many different reptiles are used by humans for many different purposes, such as foods, medicines, or as pets. Alves et al., (2009b) listed nine reptile species (including $B$. constrictor) that are used in Brazil for both food and medicinal purposes. While Brazilian law prohibits the commercialization of wild animals, whole animals or their parts can easily be found being sold in public markets for different purposes (Alves \& Pereira-Filho 2007, Alves et al. 2007a). The multiple human uses of these animals represent an additional source of environmental pressure on this species, although the precise degree of impact will need to be more closely evaluated and contextualized (Alves \& Rosa 2006, Alves et al. 2007b, Alves et al. 2009b). As pointed out by McMichael \& Beaglehole (2000), many of today's public health issues have their roots in the same socioeconomic inequalities and imprudent consumption patterns that jeopardize the future sustainability of health. There is a need to promote conservation and to protect species utilized for medicinal purposes considering all the potential of these species, because bioprospecting is one of the incentives for the conservation of species (Kursar et al., 2007).

This situation demonstrates the importance of developing more detailed studies focusing on the interactions between humans and reptiles in order to be able to evaluate the true implications of the use of these animals for medicinal purposes and to develop viable strategies for their conservation (Ferreira et al., 2009c).

The hunting and sale of wild animals, including $B$. constrictor, is prohibited in Brazil. However, the commercial use of these animals as pets is possible by breeding the snakes in captivity, thereby reducing the pressure on wild populations (Marešová \& Frynta, 2008). According to Alves et al. (2009b), a viable proposal might be the creation of cooperatives in rural communities to breed these reptiles for the medicinal and magic/religious markets. These cooperatives could breed any number of reptile species for commercial purposes with the appropriate authorization and regulation of governmental agencies and the guidance of specialists in the area (biologists, veterinarians and zootechnicians).

In view of the above, strategies for the rational use of products of $B$. constrictor should be idealized for the conservation this species. We also recommend that governmental environmental and health agencies intensify their control over the commercialization of products derived from animals in public markets, considering the indiscriminant commercial use of native species for medicinal purposes has been cited as one of the probable causes of the population declines noted in many plant and animal species (Alves \& Rosa, 2005, 2007a,b).

\section{Conclusions}

Our results indicate that the body fat of $\mathrm{Boa}$ constrictor does not possess bactericidal activity, from the clinical point of view, but when combined with an antibiotic, the fat demonstrated a significant synergistic activity. The use and sale of products derived from Boa constrictor can tend to exert pressure on the wild populations of this species. Therefore, we recommend the following measures: i) development of management plans for a sustainable and rational use of this species, reducing the possible pressure on this species; and ii) more studies focusing on the use of body fat of Boa constrictor in the treatment of other illnesses.

\section{Acknowledgements}

The authors would like to thank the CAPES for the scholarships to FSF, SVB and the Funcap for the scholarships to EFFM and for support to Waltécio O. Almeida and José G. M. Costa (processo BPI-01122.05/08); IBAMA for collecting permission (007/ 2007 CGFAP/IBAMA 02007.001009/2004) Many thanks to A. Leiva for reviewing the manuscript.

\section{References}

Adhya M, Singha B, Chatterjee BP 2009. Purification and characterization of an $\mathrm{N}$-acetylglucosamine specific lectin from marine bivalve Macoma birmanica. Fish Shellfish Immunol 27: 1-8.

Albuquerque UP, Araújo TAS, Ramos MA, Nascimento VT, Lucena RFP, Monteiro JM, Alencar NL, Araújo, EL 2009. How ethnobotany can aid biodiversity conservation: reflections on investigations in the semi-arid region of NE Brazil. Biodivers Conserv 18: 127-150.

Almeida AV 2007. Zooterapia indígena brasileira do século XVII nas obras de Guilherme Piso, Georg Marcgrave e Joannes de Laet. Sitientibus 7: 261-272.

Alves RRN, Léo Neto NA, Santana GG, Vieira WLS, Almeida WO 2009a. Reptiles used for medicinal and magic religious purposes in Brazil. Appl Herpetol 6: 257-274.

Alves RRN, Léo Neto NA, Brooks SE, Albuquerque UP 2009b. Commercialization of animal-derived remedies as complementary medicine in the semi-arid region of northeastern Brazil. J Ethnopharmacol 124: 600-608.

Alves RRN, Lima NH, Tavares, MC, Souto WMS, Barboza RRD, Vasconcellos A 2008. Animal-based remedies as complementary medicines in Santa Cruz do Capibaribe, Brazil. BMC Complement Altern Med 8: 44-52.

Alves RRN, Pereira Filho GA 2007. Commercialization and use of snakes on North and Northeastern Brazil: implications for conservation and management. Biodivers Conserv 16: 969-985.

Alves RRN, Rosa IL, Santana GG 2007. The role of animal- 
derived remedies as complementary medicine in Brazil. BioScience 57: 949-955.

Alves RRN, Rosa IL 2006. From cnidarians to mammals: The use of animals as remedies in fishing communities in NE Brazil. J Ethnopharmacol 107: 259-276.

Alves RRN, Rosa IL 2005. Why study the use of animal products in traditional medicines? J Ethnobiol Ethnomed 1: 1-15.

Alves RRN, Rosa IL 2007a. Zootherapeutic practices among fishing communities in North and Northeast Brazil: a comparison. J Ethnopharmacol 111: 82-103.

Alves RRN, Rosa IL 2007b. Zootherapy goes to town: The use of animal-based remedies in urban areas of NE and $\mathrm{N}$ Brazil. J Ethnopharmacol 113: 541-555.

Alves RRN, Vieira WLS, Santana GG 2007b. Reptiles used in traditional folk medicine: conservation implications. Biodivers Conserv 7: 2037-2049.

Alves RRN 2008. Animal-based remedies as complementary medicine in Brazil. Res Complement Med 15: 4-4.

Alves RRN 2009. Fauna used in popular medicine in Northeast Brazil. J Ethnobiol Ethnomed 5: 1-11.

Andrade JN, Costa-Neto EM 2006. O comércio de produtos zooterápicos na cidade de Feira de Santana, Bahia, Brasil. Sitientibus 6: 37-43.

Ang HH, Lee KL 2006. Contamination of mercury in tongkat Ali hitam herbal preparations. Food Chem Toxicol 44: 1245-1259.

Barros CM, Andrade LR, Allodi S, Viskov C, Mourier PA, Cavalcante MCM, Straus AH, Takahashi HK, Pomin VH, Carvalho VF, Martins MA, Pavão MS 2007. The hemolymph of the ascidian Styela plicata (ChordataTunicata) contains heparin inside basophil-like cells and a unique sulfated galactoglucan in the plasma. $J$ Biol Chem 282: 1615-1626.

Bosch TCG, Augustin R, Anton-Erxleben F, Fraune S, Hemmrich G, Zill H, Rosenstiel P, Jacobs G, Schreiber S, Leippe M, Stanisak M, Grötzinger J, Jung S, Podschun R, Bartels J, Harder J, Schröder JM 2009. Uncovering the evolutionary history of innate immunity: The simple metazoan Hydra uses epithelial cells for host defence. Develop Comp Immunol 33: 559-569.

But PP, Lung L, Tam Y 1990. Ethnopharmacology of rhinoceros horn. I: Antipyretic effects of rhinoceros horn and other animal horns. J. Ethnopharmacol. 30: 157-168.

Chin Y, Balunas MJ, Chai HB, Kinghorn AD 2006. Drug discovery from natural sources. AAPS J 8: 239-253.

Chivian E 2002. Biodiversity: Its importance to human health Center for Health and the Global Environment. Harvard Medical School.

Conlon JM, Leprince J, Vaudry, H, Jiansheng H, Nielsen PF 2006. A family of antimicrobial peptides related to japonicin-2 isolated from the skin of the chaochiao brown frog Rana chaochiaoensis. Comp Biochem Physiol 144: 101-105.

Costa-Neto EM 2000. Conhecimento e usos tradicionais de recursos faunísticos por uma comunidade afro-brasileira. Resultados preliminares. Interciencia 25: 423-431.

Costa-Neto EM 1999. Healing with animals in Feira de Santana city, Bahia, Brazil. J Ethnopharmacol 65: 225-230.

Coutinho HD, Vasconcellos A, Freire-Pessôa HL, Gadelha CA, Gadelha TS, Almeida-Filho GG 2010. Natural products from the termite Nasutitermes corniger lowers aminoglycoside minimum inhibitory concentrations.
Phcog Mag 6: 1-4.

Coutinho HDM, Vasconcellos A, Lima MA, Almeida-Filho GG, Alves RRN 2009. Termite usage associated with antibiotic therapy: enhancement of aminoglycoside antibiotic activity by natural products of Nasutitermes corniger (Motschulsky 1855). BMC Complement Altern Med 9: 35-38.

Coutinho HDM, Cordeiro LN, Bringel KP 2005. Antibiotic resistance of pathogenic bacteria isolated from the population of Juazeiro do Norte - Ceará. Rev Bras Cienc Saude 9: 127-138.

Cox PA 1990. Ethnopharmacology and the search for new drugs. In Bioactive Compounds from Plants. Edited by: Anonymous. Ciba Foundation Symposium 154. Wiley Interscience, New York, p. 40-47.

Eliopoulos GM, Moellering RC 1991. Antimicrobial combinations. In: Lorian V (Ed). Antibiotics in laboratory medicine. Baltimore, p. 434-441.

Falodun A, Owolabi OJ, Osahon O 2008. Physicochemical, antimicrobial and anti-inflammatory evaluation of fixed oil from Boa constrictor. Acta Pol Pharm Drug Res 65: 477-480.

Fan C, Zhang S, Li L, Chao Y 2008. Fibrinogen-related protein from amphioxus Branchiostoma belcheri is amultivalent pattern recognition receptor with a bacteriolytic activity. Mol Immunol 45: 3338-3346.

Ferreira FS, Brito SV, Ribeiro SC, Almeida WO, Alves RRN 2009a. Zootherapeutics utilized by residents of the community Poço Dantas, Crato-CE, Brazil. J Ethnobiol Ethnomed 5: 21-31.

Ferreira FS, Brito SV, Ribeiro SC, Saraiva AAF, Almeida WO, Alves RRN 2009b. Animal-based folk remedies sold in public markets in Crato and Juazeiro do Norte, Ceara, Brazil. BMC Complement Altern Med 9: 17-24.

Ferreira FS, Brito SV, Costa JGM, Alves RRN, Coutinho HDM, Almeida WO 2009c. Is the body fat of the lizard Tupinambis merianae effective against bacterial infections? J Ethnopharmacol 126: 233-237.

Freitas FI, Guedes-Stehling E, Siqueira-Júnior JP 1999. Resistance to gentamicin and related aminoglycosides in Staphylococcus aureus isolated in Brazil. Lett Appl Microbiol 29: 197-201.

Hadacek F, Greger H 2000. Testing of Antifungal natural products: methodologies, comparability of results and assay choice. Phytochem Anal 11: 137-147.

Harvey AL 2008. Natural products in drug discovery. Drug Discov Today 13: 894-901.

Henderson RW, Micucci TWP, Puorto G, Bourgeois RW 1995. Ecological correlates and patterns in the distribution of neotropical boines (Serpentes: Boidae): a preliminary assessment. Herpetol Nat History 3: 15-27.

Houghton PJ, Howes MJ, Lee CC, Steventon G 2007. Uses and abuses of in vitro tests in ethnopharmacology: visualizing an elephant. J Ethnopharmacol 110: 391-400.

Hunt B, Vincent ACJ 2006. Scale and sustainability of marine bioprospecting for pharmaceuticals. Ambio 35: 57-64.

Javadpour MM, Juban MM, Lo WC, Bishop SM, Alberty JB, Cowell SM, Becker CL, McLaughlin ML 1996. De novo antimicrobial peptides with low mammalian cell toxicity. J Med Chem 39: 3107-3113.

Ju L, Zhang S, Liang Y, Sun X 2009. Identification, expression 
and antibacterial activity of a tachylectin-related homolog in amphioxus Branchiostoma belcheri with implications for involvement of the digestive system in acute phase response. Fish Shellfish Immunol 26: 235-242.

Kong D, Li X, Zhang H 2009. Where is the hope for drug discovery? Let history tell the future. Drug Discov Today 14: 115-119.

Kursar TA, Caballero-George CC, Capson TL, Cubilla-Rios L, Gerwick WK, Heller MV, Alicia Ibañez A, Linington RG, McPhail KL, Ortega-Barría E, Romero LI, Coley PD 2007. Linking bioprospecting with sustainable development and conservation: the Panama case. Biodivers Conserv 16: 2789-2800.

Lee SKH 1999. Trade in traditional medicine using endangered species: an international context. Proceedings of the second Australian Symposium on traditional medicine and wildlife conservation, Melbourne Australia.

Lev E 2003. Traditional healing with animals (zootherapy): medieval to present-day Levantine practice. $J$ Ethnopharmacol 85: 107-118.

Li Y, Zhang Y, Shen X, Guo Y 2009. A novel sesquiterpene quinone from Hainan sponge Dysidea villosa. Bioorg Med Chem Lett 19: 390-392.

Marešová J, Frynta D 2008. Noah's Ark is full of common species attractive to humans: The case of boid snakes in zoos. Ecol Econ 64: 554-558.

Mayer AMS, Gustafson KR 2008. Marine pharmacology in 2005-2006: Antitumour and cytotoxic compounds. Eur J Cancer 44: 2357-238.

McCue MD 2008. Fatty acid analyses may provide insight into the progression of starvation among squamate reptiles. Comp Biochem Physiol 151: 239-246.

McMichael AJ, Beaglehole R 2000. The changing global context of public health. Lancet 356: 495-499.

Park T, Kim T, Choi S, Kim Y 2009. Cloning, expression, isotope labeling, purification, and characterization of bovine antimicrobial peptide, lactophoricin in Escherichia coli. Protein Expr Puri 65: 23-29.

Peters JA, Orejas-Miranda B, Vanzolini PE 1986. Catalogue of Neotropical Squamata. Smithsonian Institution Press:
Washington and London.

Rashid ZM, Lahaye E, Defer D, Douzenel P, Perrin B, Bourgougnon N, Sire O 2009. Isolation of a sulphated polysaccharide from a recently discovered sponge species (Celtodoryx girardae) and determination of its anti-herpetic activity. Int J Biol Macromol 44: 286-293.

Servheen C 1999. The trade in bears and bear parts. In: Servheen C, Herrero S, Peyton B. Bears - Status survey and conservation action plan. IUCN/SSC Bear and Polar Bear Specialist Groups, IUCN, Grand, Switzerland, Cambridge, UK. 33-38.

Silva MLV, Alves ÂGC, Almeida AV 2004. A zooterapia no Recife (Pernambuco): uma articulação entre as práticas e a história. Biotemas 17: 95-11.

Stankevicins L, Aiub C, Santa Maria LC, Lobo-Hajdu G, Felzenszwalb I 2008. Genotoxic and antigenotoxic evaluation of extracts from Arenosclera brasiliensis, a Brazilian marine sponge. Toxicol in Vitro 22: 18691877.

Stow A, Beattie A 2008. Chemical and genetic defenses against disease in insect societies. Brain Behav Immun 22: 10091013.

Vanzolini PE, Ramos-Costa AMM, Vitt LJ 1980 Répteis das Caatingas. Academia Brasileira de Ciências: Rio de Janeiro, Brasil.

Wang KJ, Cai JJ, Cai L, Qu H, Yang M, Zhang M 2009. Cloning and expression of a hepcidin gene from a marine fish (Pseudosciaena crocea) and the antimicrobial activity of its synthetic peptide. Peptides 30: 638-646.

Zheng CJ, Yoo JS, Lee TG, Cho HY, Kim YH, Kim WG 2005. Fatty acid synthesis is a target for antibacterial activity of unsaturated fatty acids. FEBS Letters 579: 5157-5162.

\section{*Correspondence}

\section{Felipe S. Ferreira}

Departamento de Sistemática e Ecologia, Centro de Ciências Exatas e da Natureza, Universidade Federal da Paraíba

Campus I, 58051-900 João Pessoa-PB, Brazil

Email address: ferreira_fs@dse.upb.br 